\title{
New challenges in franchisor-franchisee relationship. An analysis from agency theory perspective
}

\author{
Nuevos retos en las relaciones franquiciador- \\ franquiciado. Un análisis desde la teoría de la agencia
}

\author{
Guillermo Navarro SAnFelix ${ }^{1}$ \\ Francisco PUig ${ }^{1}$ \\ Universidad de Valencia (España)
}

Recibido el 30 de diciembre de 2015, aceptado el 6 de julio de 2016

Publicado online el 19 de julio de 2017

$\mathrm{N}^{\mathrm{o}}$ de clasificación JEL: M00, M130

DOI: $10.5295 / \mathrm{cdg} .150610 \mathrm{gn}$

\begin{abstract}
:
Agency theory has been widely used in the franchising literature. This theory analyzes the contract relationships between the principal and agent and has been mostly applied to franchising in traditional sectors (e.g., restaurants, retailing, or travel agencies) where the processes and procedures can be easily standardized. Recently, there has been a spectacular development of high-intensity knowledge sectors, especially in the health sector (dentists, opticians, physiotherapists etc.), where many companies choose franchising to expand the network and improve the survival rates of franchisees, although this strategy goes against the traditional view of the agency theory.

In this work, we propose to study this "new agency problem”, using the franchising business model as our research field. The know-how in high-knowledge-intensive sectors is difficult to codify and transfer, and it opens new possibilities for resource-based and intellectual capital perspectives to explain how knowledge assets are built into contracts in franchisor-franchisee relationships. Using resource-based theory and an intellectual capital perspective, we develop propositions on how to handle the knowledge transfer more efficiently. From this point of view, we propose an interorganizational dynamic contract to provide a more efficient knowledge transfer, thereby contributing to the success of the franchise networks as well as reducing the failure rates of franchisees' outlets.
\end{abstract}

Keywords:

Franchise, agency theory, entrepreneurship, resource-based view.

\section{Resumen:}

La Teoría de la Agencia está ampliamente extendida en la literatura sobre el modelo de negocio de la franquicia. Desde la misma se analiza el contenido del contrato que gestiona la relación entre Principal y Agente en actividades y procesos fácilmente estandarizables (restauración, comercio minorista, agencias de viaje, etc.). No obstante, durante los últimos 10 años ha habido un espectacular desarrollo de ese modelo empresarial hacia

${ }^{1}$ Dpto. Dirección de Empresas "Juan J. Renau". Facultad de Economía. Avda. Tarongers, s/n. 46022, Valencia (Spain).guinasan@alumni.uv.es; francisco.puig@uv.es 
sectores más intensivos en conocimiento (dentistas, ópticas, fisioterapia, etc.) que cuestiona algunos de los postulados básicos de la teoría, limitando las posibilidades de desarrollo y supervivencia del proyecto.

En este trabajo revisamos el "nuevo problema de agencia" de Agencia que surge cuando un emprendedor franquicia una actividad intensiva en Capital Intelectual. Consideramos que las actividades que se realizan en estos sectores presentan una complejidad tal que hace difícilmente codificable y transmisible todos sus aspectos, por lo que el uso de los Contratos típicos de Agencia puede quedar muy limitado. Por ello, a partir del marco de la Teoría de Recursos y Capacidades planteamos un conjunto de proposiciones que sugieren un contrato dinámico interorganizacional y donde la efectiva transferencia de conocimientos entre las partes se convierte en un aspecto clave. En última instancia las contribuciones del mismo permitirán reducir las tasas se disolución de esos proyectos.

\section{Palabras clave:}

Franquicia, teoría de la agencia, emprendimiento, teoría de recursos y capacidades. 


\section{INTRODUCTION}

Franchising can be seen as a contract for a period of time in which the owner of a trademark (franchisor) gives an entrepreneur or an organization (franchisee) the right to operate under its brand in exchange for an entry fee and royalties (Caves and Murphy 1976). The result of this agreement is the provision by an establishment of a service whose value is perceived by the customer as equal to, or higher than a similar one offered under other business models (Christopher 1996). Given the survival rates recorded under this model, it can be treated as a valid alternative for the creation and development of enterprises (Ayling 1988; Castrogiovanni et al. 1993; Michael and Combs 2008). In recent years, the volume of activity generated under the franchise formula has experienced a boom and growth worldwide. For 2016, an increase in turnover of 5.8\% is expected, with a remarkable rise being anticipated especially in the hotels and restaurants $(6.3 \%)$, products and retail services $(6.4 \%)$, and logistics (6.6\%) sectors (IFA 2016). Franchising is similarly important in Spain, where according to the latest edition of the Franchisors' White Book (AEF 2015), there are over 64,000 franchise outlets, 250,000 direct jobs, a turnover of about 26,000 million euros, and an activity level that has increased by more than $120 \%$ in the last 10 years.

There are several reasons that seem to explain the rise and development of the franchising business model:

- It allows the franchisor to expand and enter new markets more quickly.

- It allows the entrepreneur to create a business and achieve self-employment while taking lower risks.

Although franchising is not the only alternative for an entrepreneur, the truth is that in many sectors it enjoys great popularity, especially in the retail and hostelry sectors (Alon et al. 2012; Croonen and Brand 2013; Hua and Dalbor 2013). Despite that success, with the recent expansion of this business model towards less conventional sectors, especially, which are called "intellectual capital intensive sectors" (IC) (Pena 2002), such as physiotherapy, dentistry, and counseling, certain limits are becoming clear.

Some of the limits than can appear arise from disagreements with regard to the tasks that each of the parties must assume, the duration of the contract, and the mechanisms for knowledge transfer. Ultimately, these aspects can lead to situations in which undertakings under the franchise formula make the franchising option a riskier choice (Bates 1995).

Indeed, from an agency theory perspective (AT), a franchise is described as one agent (franchisee) conducting an activity and paying the principal (franchisor) an entry fee and some royalties. The principal indoctrinates, delegates, and organizes the work. Meanwhile, the franchisee has the right to exploit the franchisor's business model for a period of time and under certain conditions (Lafontaine 1992; Pardo-del-Val et al. 2014.). However, the static and economic position in which the AT lies cannot address other situations in which there are activities where part or all of the most valuable resources are in the possession of the franchisee (Gonzalez-Diaz and Solis-Rodriguez 2012), and those resources and capabilities are dynamic (Blut et al. 2011). Some of these resources are classified as intangible or intellectual capital (human, structural, and relational) (Petty and Guthrie 2000; Watson and Stanworth 2006). Ultimately, that dissonance in the content and duration of the contract can cause major problems between the parties and, as a result, a premature dissolution (Ring and Van de Ven 1994). 
Therefore, the aim of this study is to predict the agency problems (APs) that can arise when an entrepreneur starts an IC activity using the franchising business model and propose alternatives to identify and overcome those problems. To that end, we will review the main literature related to this topic and seek solutions provided by a resource-based view of the firm (RBV), whose basic postulates argue that the results of companies are different because of the different endowments and combinations that they have. As a result of this analysis we put forward a set of propositions that suggest, with certain organizational assumptions, the need for a new, more flexible, and cooperative conceptual model between the parties.

\section{THEORICAL FRAMEWORK}

\subsection{Review of agency theory in franchising business model}

The AT became popular in the 1970s with the work of Ross (1973), Caves and Murphy (1976), Jensen and Meckling (1976), and Fama and Jensen (1983a and 1983b). This theory emerged as one that motivates companies to separate the ownership and control of the company. It is considered to be a multidisciplinary theory that is able to be used for other fields such as accounting, economics, finance, marketing, political science, and behavior among organizations or societies (Eisenhardt 1989; Cuevas-Rodríguez et al. 2012), and is defined as "an agency relationship by which one party, the principal, delegates work elsewhere, to the agent, to carry out this work"(Eisenhardt 1989, p.58).

The work of Ross defines the agency relationship as "a relationship that arises between two parties when a designated agent acts as or on behalf of the other, the designated principal, in one aspect of decision making" (1973, p.134). In addition, under an economic approach it exposes the reasons why, acting in perfect market conditions, it is feasible to separate the management of the company's property.

Later, Jensen and Meckling define the agency relationship as being under "a contract in which the principal commits the agent to develop an activity in favor of this, delegating decision-making and authority to the agent" (1976, p.308), and establish that the agency costs are the sum of the costs for the design and formalization of the contracts, the costs of monitoring the agent, the bond, and those associated with the residual loss. Moreover, in their study they refine aspects such as the optimal size of the outlet, the costs of hiring the agent, and the costs of the tracking or monitoring of agent activity.

In 1983, Fama and Jensen (1983a and 1983b) gave the AT a legal approach. In these works, they develop the main aspects on which the agency agreement between the parties (Fama and Jensen 1983a) is negotiated. Among them, they consider that some aspects can lead to negotiations between the principal and agent; these issues are decentralized decision making, supervision of the principal's demands, and establishing flexible rules. In a later work, these authors establish the main mechanisms to reduce the APs that may arise between the parties (Fama and Jensen 1983b).

For AT, the main unit of analysis is the contract established between the parties, which are linked. AT looks for a relationship that is as efficient as possible between the principal and agent, whether they are individuals, organizations, or information (Eisenhardt 1989). 
The main obstacles that must be addressed to optimize this contract are the APs and risk sharing (RS).

This theory has been used to argue many aspects that are based on two or more actors, such as a business model franchise (Shane 1998), separation of ownership and control (Letza et al. 2004), mergers and acquisitions, opportunistic behavior between managers and subordinates (El-Akremi et al. 2010; Mellewight et al. 2011), or an associated enterprise (Michael and Combs 2008; Salar and Salar 2014).

\subsection{The entrepreneur as franchisee from an agency theory perspective}

Authors like Venkataraman define the entrepreneur as "a person who analyzes the how, who and with what effect to create future goods or services that can be discovered, evaluated and exploited" (1997, p.120). This conception of the entrepreneur implies that academics should, among other things, study the sources of the opportunities developed by entrepreneurs and the way they exploit those opportunities (Shane and Venkataraman 2000).

The entrepreneur and his or her actions have been studied in the franchising sector from different perspectives. For example, the theory of resources and capabilities (Fladmoe-Lindquist 1996; Juste et al. 2006; Alon et al. 2012; Michael 2014), scarcity resource theory (Combs et al. 2011a; 2011b; Hua and Dalbor 2013), transaction costs theory and the theory of the firm (Rubin 1973 and 1978; Michael and Moore 1995; Baena 2010), social exchange theory (Altinay et al. 2014), structural inertia theory (Winter et al. 2012), and game theory (Desai 1997; Sigué and Chintagunta 2009).

Under AT studies have focused on the entrepreneurial franchisee (agent) suggesting that those entrepreneurs who are interested in that kind of business model are looking for activities that offer more guarantees and lower risk, even at the expense of a loss of independence and future profitability (Ayling 1988; Castrogiovanni et al. 1993; Michael and Combs 2008). The research by scholars such as Kaufmann (1999) and Kaufmann and Eroglu (1999) reflects this dichotomy between being an entrepreneur franchisee or not and proposes an integrative model that considers other aspects, such as individual and social aspects. Seawright et al. (2013) compared managers and entrepreneur-franchisees. They analyzed the attitudes of the managers of establishments owned by the chain and traditional entrepreneurs and came to the conclusion that franchisees have a profile more similar to a traditional manager than an entrepreneur; these franchisees exhibit a maximum commitment to the chain but have lower skills than managers or independent entrepreneurs.

The entrepreneur who becomes a franchisee is involved in negotiating the franchise agreement. These contracts are born as a result of market opportunities (market-like qualities) in which the franchisor develops a product or service that the franchisee put on the market, or they arise as a result of the franchisor's market power (firm-like qualities), where this provides the franchisee with assistance in establishing the business (Norton 1988).

Although some studies, like that of Mellewight et al. (2011), evaluate the results of contracts in terms of employee satisfaction, there are still significant gaps in respect of examples of premature dissolution and failure. In that vein, Gillis and Castrogiovanni (2012) suggest the use of new or expanded paradigms such as the RBV. In a similar vein are the 
proposals made by Dant (2008), who argues that the research in this field must go beyond the study of the "McDonald's effect" and should be expanded to different sectors such as hotels and restaurants; new explanations should be sought about the challenges that this business model is facing, such as the AP and RS.

\subsection{The agency problem in franchising}

In a franchise outlet, the AP arises when the objectives differ between the principal and agent. One aspect where this is most visible is in the so-called moral hazard; so to prevent this problem, the principal sets some restrictive clauses (Lafontaine 1992). There are at least two different types of moral hazard:

- $\quad$ One-sided moral hazard, in which the agent may want to take unfair advantage of knowledge made available by the principal;

- $\quad$ Two-sided moral hazard, in which either party can behave unfairly.

The other dissonance arises from the so-called adverse selection, which is produced when the principal detects that the agent is lacking in a number of the skills needed to perform the task or function (Eisenhardt 1989).

The AP, whether it be either moral hazard or adverse selection, has been demonstrated and its effects studied on many aspects. These aspects include the origin of the relationship between organizations (Caves and Murphy 1976; Gillis and Castrogiovanni 2012), with regard to coordination mechanisms for compensation and financing (Sen 1993; Wimmer and Garen 1997; Vázquez 2005; Gonzalez-Diaz and Solis-Rodriguez 2012), the duration and optimization of the agency contract (Shane 1998; Vázquez 2007), the control mechanisms on performance (El Akremi 2010; Mellewigt et al. 2011), the risks in the relationship (Lafontaine 1992; Michael and Combs 2008), and the propensity to franchise by franchisors (Lafontaine 1992; Barthélemy 2011; Seawright et al. 2013). In general, the literature concludes that to overcome the AP in a franchise outlet, it is important to identify these risks at an early stage, even before the business commences. For this task, the key element is to obtain a good evaluation of the parties. However, we argue that these are short range recommendations, since most studies have been carried out only from the point of view of the principal and only in respect of sectors that are traditionally franchised.

\subsection{The risk sharing in franchising}

The other problem that exists under the AT is the RS, which is based on the simultaneous perception of the both principal and agent (i.e., an asymmetric risk sharing), so there is no assumption that all of the risks are known before the start of the activity. Thus, if any of the parties observe inequalities, RS can cause individualistic behavior, either because one of the parties can benefit unilaterally from the knowledge provided in the agency relationship to end the relationship (free riding), or by the premature abandonment or withdrawal of the agency relationship (hold-up) (Vazquez 2007). The negative effects of this tension have been studied in respect of the quality of service offered by the franchisor (Grace and Weaven 2011) or in the image and value of the franchised trademark (Nyadzayo et al. 2015). 
Indeed, although the franchise agreement simultaneously reduces the risk to both parties of an exchange of resources and capabilities, evaluating them and their future development are more complex to implement. For this purpose, franchisors set broadly based royalties, whether they be fixed or variable or a combination of both (Lafontaine and Bhattacharyya 1995). In other cases, franchisors set profiles and clauses requiring franchisees to have certain training, experience, and a unique active involvement in the project (not only as investors) in exchange for some autonomy and the fixing of the franchise territory (Michael and Combs 2008). On the other hand, Windsperger and Dant (2006) address this issue from the aspect of property rights theory, which affirms that the more difficult it is to articulate aspects of the relationship in the contract, the more influence the franchisee gets once they have learned the know-how of the company. Therefore, the relationship established between the parties will depend on the ability to specifically capture the content of the relationship, and this will vary according to the difficulty of defining, codifying, and teaching these matters for purposes of the contract (Zander and Kogut 1995). In any case, the emergence of a need to go beyond some new franchised realities (activities) may be evidence of unforeseen situations that require further investigation.

\section{THE AGENCY PROBLEMS AND RISK SHARING IN INTELLECTUAL CAPI- TAL INTENSIVE SECTORS}

The traditional franchise has involved an agency relationship in which the franchisor provides mainly the "know-how", technical assistance, and brand image, while the franchisee provides the work and local market knowledge (Gasset 1992). The AT also states that although there is a cooperative relationship between the parties, there is an asymmetry of power whose origin lies in the different resourcing and capabilities ${ }^{2}$ possessed by each party (Norton 1988 Hossain and Wang 2006). This difference in endowments, which can be dynamic but linear, is managed with an entry fee and royalties that are disbursed over time.

With the wider use of the strategy of cooperation by companies and the implementation of franchising in other sectors that are more intensive in knowledge activities, new realities and challenges have emerged that require new management capabilities (Vazquez 2005). These new sectors can be characterized by different dimensions, such as the scope of activity (local or international) and the volume of investment or knowledge. From the latter perspective, Pena (2002) differentiates sectors by intensive and non-intensive $\mathrm{IC}^{3}$. There are three IC components (Stewart and Ruckdeschel 1997; Petty and Guthrie 2000; Watson and Stanworth 2006): human capital, structural capital, and relational capital.

\footnotetext{
${ }^{2}$ We understand resources to be the "aspects (tangible or intangible) that are available to a company or organization" (Wernerfelt 1984, p.172), and we also refer to skills and competences that belong to each of the parties. As Teece et al. (1997) stated, we prefer to consider resources as "specific assets of the organization." However, we use the word resource to be consistent with the existing literature.

${ }^{3}$ We do not have to confuse Intellectual Capital (IC) with Knowledge Management (KM). Although both concepts are based on the value of information, KM is the tool used by organizations to control and distribute the IC (Petty and Guthrie 2000, p.159).
} 
With this approach (Figure 1), human capital in a franchise comprises skills, experiences, attitudes, ideas, and values. For the franchisor this dimension involves the training, knowledge, and skills they bring to the relationship, while the franchisee contributes with prior training, knowledge of the local market, and innovation in processes, royalties, and entry fees. An intensive IC franchisee brings its knowledge and experience, local market knowledge, and consistent royalties in securing the acquisition of the improvements made by the franchisor. Structural capital consists of the processes and infrastructure, with contributions from the principal's logistics support, marketing, and information. The agent's contribution comprises the use of specialized and new techniques for improving the tasks. Relational capital is formed by the nature and quality of the relationships established in the business. For the franchisor, this dimension encompasses the contracts with suppliers, and for the franchisee, it encompasses the local brand development and the customer loyalty achieved.

Figure 1

\section{Resources and capabilities provided by the parties in a franchising intellectual capital intensive relationship}

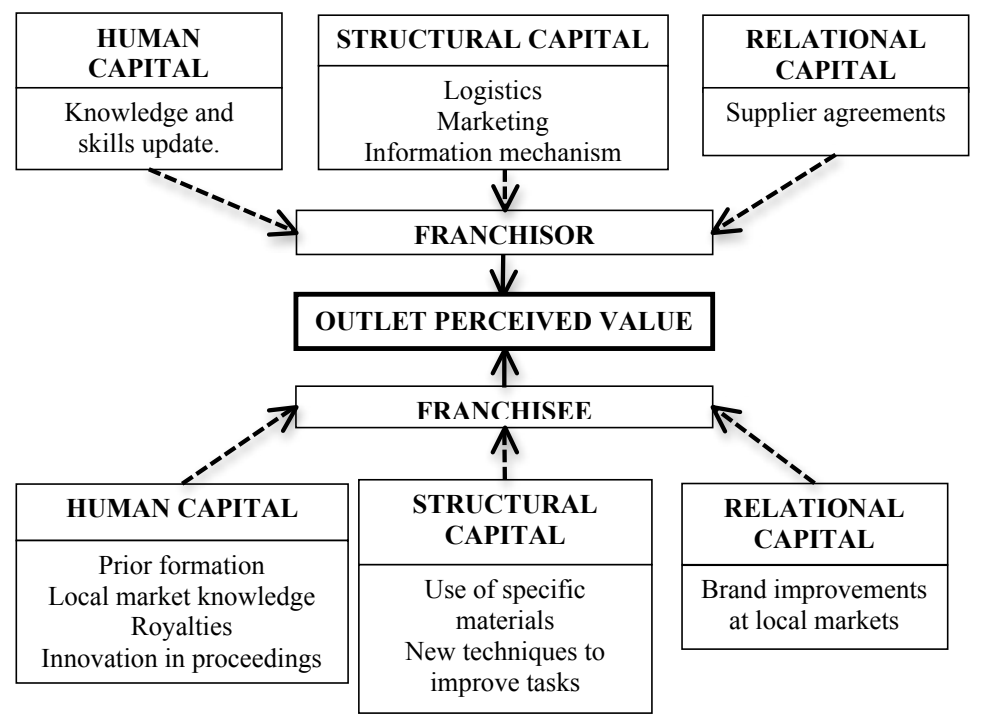

Source: Own elaboration based on Watson and Stanworth (2006, p.345).

The higher the value of each of these components, the greater its contribution to the IC of the contract and, as a consequence, the greater the perceived value of the outlet ${ }^{4}$.

\footnotetext{
${ }^{4}$ The customer's perceived value of the outlet is the resulting subjective balance of the transaction. When this is positive, it translates into a belief that the benefit has been greater than the cost of the acquisition (Christopher 1996). In $\mathrm{B} 2 \mathrm{~B}$ relationships, a positive perception is crucial to the success of the relationship between the companies.
} 
In non-intensive IC sectors, most of the IC is in the possession of the franchisor. For example, in hostelry and retailing, where there is standardization of processes, services, and structural and relational capital, in many cases with suppliers, it is very evident that the IC is basically in the hands of the principal (Dada and Watson 2012; Croonen and Brand 2013). In addition, in those sectors where the differential IC of both parties is usually stable over time, it is the principal who develops the most innovations in the facilities and contributes to a greater extent to increasing the perceived value of the outlet. The innovative role of the agent is reduced to following the guidelines established by the principal, so development of the IC is much neglected in these circumstances. In this case, the AP and RS are minimized with a contract containing safeguards to prevent unfair, opportunistic, or unexpected behavior.

Figure 2 depicts theoretically the evolution of the IC of the parties as two parallel lines. The IC franchisor shows a higher level due to their greater possession of IC and uses the royalties as a compensation mechanism for their input of IC. From a temporal point of view, the royalties paid by the franchisee throughout the entire relationship are expected to be proportionally constant.

Figure 2

\section{Relation between franchisor and franchisee intellectual capital in traditional franchising sectors}

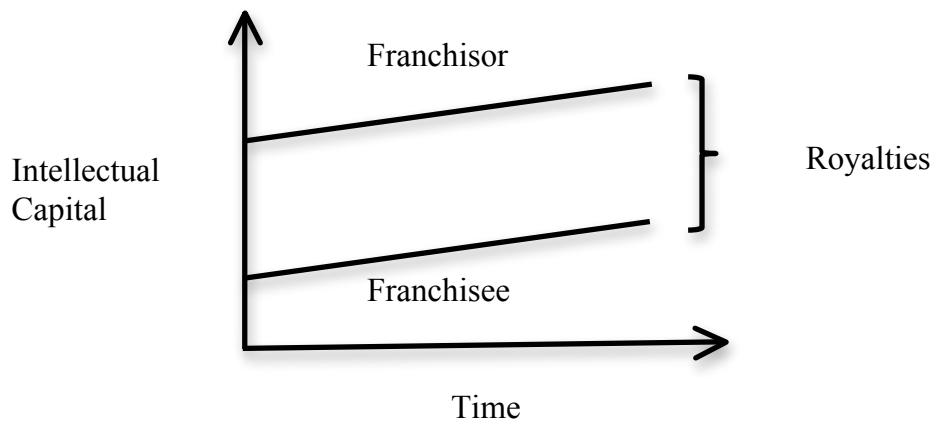

Source: Own elaboration.

In contrast (Figure 3), in intensive IC sectors it is much more difficult to standardize activities and processes and the contribution to the perceived value of the outlet by the franchisee is much greater and more significant (Marie Doherty et al. 2014; Nyadzayo et al. 2015). Although the resources provided by the franchisor have a very high value at the beginning of the relationship, and franchisees pay royalties for that (the franchisor provides a recognizable brand, efficient processes, specific machinery, etc.), over time, after learning the necessary tasks we expect the agent will reduce its dependence on the franchisor to perform the work and theoretically also will be able to negotiate a reduction in the level of the royalties to balance the relationship. In the later stages, it can reach the situation where the franchisee has the highest IC contribution to the perceived value of the outlet (Watson and Stanworth 2006). In this case, we can expect a bigger AP and RS because the current 
circumstances are not as they were when the original contract was negotiated and unforeseen behaviors cannot be avoided.

Figure 3

\section{Relation between franchisor and franchisee intellectual capital in IC intensive sectors}

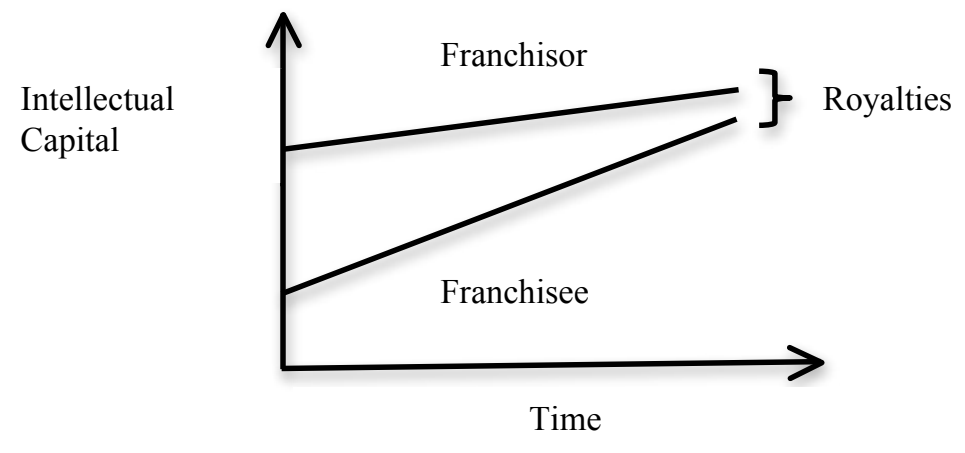

Source: Own elaboration.

In short, according to our arguments we put forward the following proposals:

Proposal 1: A perceived IC franchise is not static, it alters as the relationship develops between the parties.

Proposal 2: In establishing dynamic agency contracts, intensive IC franchises increase the chances of survival.

\section{THE CHALLENGE OF INTELLECTUAL CAPITAL TRANSFER}

At this point, it could be argued that the evolution of franchise contracts to more complex sectors show the need for new contractual models where dynamism is a key aspect. Furthermore, in those franchises where the perceived value of the outlet may depend more on the franchisee than the franchisor, such as IC intensive sectors, new management models are needed when the transfer of the IC between the parties becomes a key aspect.

The issue of knowledge transfer in franchising is not new (Benavides et al. 2008; Cumberland and Githens 2012; Gorovaia and Windsperger 2013; Okoroafor 2014). One of the aspects that has received more interest has been the assistance or support provided by the franchisor to the franchisee (Hossein and Wang 2008). However, most of these studies analyze the existing barriers and methods for the transfer of knowledge from the franchisor to the franchisee, few studies have analyzed the importance of knowledge transfer between franchisees and from franchisees to franchisors (Dada and Watson 2010).

Benavides et al. (2008) establish three IC characteristics that the franchisee must know: it must be secret between the parties; it must be essential to the development of the core business of the franchise, and should be specific to each franchisor. In addition, these au- 
thors state that to bring about an effective knowledge transfer, an operating manual must be provided by the franchisor, the knowledge transfer must be both initial and periodic, and the franchisor must provide ongoing support to the franchisee; the latter is the most important of all. Franchisees believe that the more knowledge is standardizable (encodable) the less relevance it will have to the production process and therefore the less benefit they will receive from it.

Meanwhile, Cumberland and Githens (2012) set some barriers to the tacit knowledge transfer $^{5}$, which are confidence, maturity of the relationship, communication, competition, and the existing culture. Therefore, in order to overcome these barriers, the parties must learn from one another, they must have common goals to create a single business idea (i.e., the business is perceived as shared by the parties), they must reduce domestic competitiveness, and the franchisor should establish a culture to promote and share information with franchisees.

Gorovaia and Windsperger (2013) differentiate between the strategies for information transmission, distinguishing between systems with a high degree of information (HIR) and those with low levels of information (LIR). The first group includes conferences, meetings, or visits to establishments by the franchisee, while the second group would include mail communication, manuals, and reports. The results of this study conclude that the franchisor will use more HIR according to the tacitness of the knowledge to be transmitted; the confidence between the parties plays an important role in knowledge transfer, and the more trust there is, the more systems with HIR are used.

In this regard, the advantages coming from the efficient transmission of IC between the franchisees themselves can positively affect the brand (Dada et al. 2010), giving rise to the image of the chain even being extended due to the reputation of its own workers (Watson and Stanworth 2006). Accordingly, some chains establish expensive mechanisms for transmitting knowledge that link franchisees and thereby enhance their image. The increase in the amortized costs, because of the difficulties in establishing mechanisms that are standardized within a chain franchise, can be offset to some degree by the need for less supervision (Hossein and Wang 2008).

An appropriate example of this issue is the dental franchises in Spain. These are businesses with a need for a very high level of IC for their daily work but the standardization of their processes is very similar to that required for other dental clinics. This is due to the need to use rigid protocols which, if they were not followed, would result in medical malpractice claims from aggrieved patients. The difference between this sector and other franchises traditionally lies in the demands and complexities required to replicate the processes among the different units.

With IC intensive sectors, the contributions of human, structural, and relational capital that are provided by franchisors are susceptible, with the passage of time, to being assimilated by the franchisee. When this occurs, the perceived value of the franchisor can stagnate and even reduce, thereby resulting in the emergence of various APs. To cope with this,

\footnotetext{
5 Tacit knowledge is described as that knowledge that cannot be properly expressed in verbal terms. Explicit knowledge is the kind of knowledge that can be codified and transferred. The definitions of tacit knowledge and high IC are similar, so we will use them as synonyms for a better understanding of the text.
} 
various measures can be adopted, such as a review of royalties and, if necessary, a review of the agency relationship.

Therefore, at the contractual level, the franchisee continues to pay some royalties but as every moment passes he or she finds they are getting lower levels of performance from the IC franchisor, mainly because the franchisee has already absorbed most of this (Blut et al. 2011), whereas the franchisor has the ability to draw on the new capabilities developed by the franchisees at a minimal cost. In addition, the trademark of the franchisor can be complemented by the enhanced professional image, giving added value to the relational capital provided by the franchisee. Finally, the contributions of the IC by the two parties set the actual value of the outlet that is received by the franchisee.

Therefore, with the franchisee providing an IC similar to that provided by the franchisor, we can consider the existence of a relationship that is effectively one of principal-principal when the relationship has reached a mature stage. In other words, although the franchisee could freely operate independently and avoid paying royalties, they could also choose to delegate to the franchisor some centralized activities such as marketing, procurement, recycling, and corporate image. This consideration has implications for the optimal configuration of the agency contract established between the parties (Ring and Van de Ven 1994). So far, most research on formulating the franchise agreement has been motivated to preserve the intangible heritage of the franchisor. However, the agency contract between the parties should include a part that envisages the collection in greater depth of intangible aspects (present or acquired during the contract) that should rightfully be owned by the franchisee and the entrepreneur.

Proposal 3: IC Intensive franchisors who encourage innovation in techniques and procedures among their franchisees and establish mechanisms for the transmission of these will increase the chances of survival of these establishments and therefore enhance the franchisor's chain.

\section{CONCLUSIONS}

The aim of this study was to analyze and redefine the existing inter-relational framework between the principal (franchisor) and the agent (franchisee), especially when the object of it is intensive in terms of intellectual capital activity. From that perspective we have questioned some of the basic tenets of the theory of the agency (AT) and, relying on the resource-based view (RBV), have shown some of its dysfunctionalities.

Although the more traditional approach of the franchise is based on an assumption of a symmetric and invariable relationship in time between the principal and agent, the emergence of new sectors and realities shows an agency problem (AP) that is derived from asymmetries and discontinuities that challenge the effectiveness of the model. When the entrepreneur franchisee possesses resources and idiosyncratic capabilities that are difficult for the franchisor to standardize, at a later stage of the relationship it can be more advantageous to exploit these individually.

From this approach, we suggest that a first step to reduce the various problems that might arise in an agency relationship in these sectors is an adequate prior assessment of the resources available to the parties in order to establish clear and revisable guidelines in 
the agency contract. It is a novel approach for franchising chains to consider agency relationships to be dynamic, but it can allow them access to key assets to compete successfully in these sectors that they would be unlikely to be able to acquire in another way. The role of franchisor managers in these businesses needs to be redefined. Indeed, whereas in the traditional model the franchisee is primarily a passive agent receiving the guidelines of the principal in a downward direction, in this new approach their role is more active and involves frequent interaction with the principal (franchisor), with knowledge being transmitted upstream in many cases. Undoubtedly, the latter approach can be very beneficial to both parties as it can enable them to be able to incorporate new processes and technologies, to make the franchise labor element more competitive, and can increase confidence among the parties.

Other theories, such as the dynamic resources and skills and the property rights, could provide different measures to reduce the APs. For those problems that arise from unfair conduct (two-sided moral hazard), remedial measures would involve a comprehensive assessment of the intellectual capital (IC) located in each of the parties, a mutual evaluation of these to give more balance to the relationship, and a sharing of the wealth of knowledge in both directions. With this measure the problem of adverse selection could be balanced to divide the power more evenly and thereby recognize the franchisor and franchisee skills. As for the problems associated with the risk sharing (RS) that must support the parties, franchisors should delegate more decision rights when it is difficult to replicate the intangible resources to reduce opportunistic behavior (free-riding) (Mumdžiev and Windsperger 2011). To reduce the likelihood of the premature termination of the contract (hold-up), a guarantee could be feasible that allows the franchisee to belong to other professional groups or gives territorial continuity to the franchisee to enable collateral activities to be pursued (Chu and Liu 2010).

This study has some limitations that should be mentioned. The first and most notable is that it contains conceptual ideas that need to be proven empirically. The second limitation is determined by the degree of difficulty that may be involved when evaluating some of the factors that have been described, such as the monitoring costs or effectiveness of the mechanisms of dissemination and knowledge transfer in chain establishments. Despite these limitations our work sheds some light on the uneven results of franchises among entrepreneurs and at the same time serves as a stimulus for further studies. Therefore, it is clear that future research work should be focused on the more IC intensive sectors with strong growth prospects, such as lawyers, dentists, physiotherapists, orthopedic specialists, and teaching academies and should study further the mechanisms for creating and improving confidence between the parties. In addition, it could also be of interest to study the mechanisms in these sectors for the transmission of knowledge horizontally, or between entrepreneurs (Dada et al. 2010), as well as vertically, or between entrepreneurs and customers (Dant 2008).

\section{ACKNOWLEDGEMENTS}

This investigation was supported by the Research Project UV-INV-AE16-48890 of the University of Valencia (Spain). 


\section{REFERENCES}

Alon, I., Ni, L., and Wang, Y. 2012. Examining the determinants of hotel chain expansion through international franchising. International Journal of Hospitality Management, 31(2), 379-386.

Altinay, L., Brookes, M., Yeung, R., and Aktas, G., 2014. Franchisees’ perceptions of relationship development in franchise partnerships. Journal of Services Marketing, 28(6), 509-519.

AEF (Asociación Española de Franquicias), 2015. Franquiciadores. Libro Oficial de la Asociación Española de Franquiciadores 2015. Disponible on-line, consultado el 15 de febrero de 2016: http://www.franquiciadores.com/publicaciones.php

Ayling, D., 1988. Franchising in the UK. The Quarterly Review of Marketing, 13(4), 19-24.

Baena, V., 2010. Teorías y líneas de investigación en el sistema de franquicia: una revisión desde los años 60 hasta 2009. Cuadernos de Gestión, 10, 43-66.

Barthélemy, J., 2011. Agency and institutional influences on franchising decisions. Journal of Business Venturing, 26(1), 93-103.

Bates, T., 1995. Analysis of survival rates among franchise and independent small business startups. Journal of Small Business Management, 33(2), 26-36.

Benavides, M. C. R., Rata, B. M., and Sánchez, J. I. L., 2008. Transferencia de conocimiento en la creación y en el funcionamiento de los sistemas de franquicia: un estudio empírico. Economía Industrial, (368), 227-237.

Blut, M., Backhaus, C., Heussler, T., Woisetschläger, D. M., Evanschitzky, H., and Ahlert, D., 2011. What to expect after the honeymoon: testing a lifecycle theory of franchise relationships. Journal of Retailing, 87(3), 306-319.

Castrogiovanni, G. J., Justis, R. T., and Julian, S. D., 1993. Franchise failure rates: an assessment of magnitude and influencing factors. Journal of Small Business Management, 31, 105-105.

Caves, R. E., and Murphy, W. F., 1976. Franchising: Firms, markets, and intangible assets. Southern Economic Journal, 42, 572-586.

Christopher, M., 1996. From brand values to customer value. Journal of Marketing Practice: Applied Marketing Science, 2(1), 55-66

Combs, J. G., Ketchen, D. J., Shook, C. L., and Short, J. C., 2011. Antecedents and consequences of franchising: Past accomplishments and future challenges. Journal of Management, 37(1), 99-126.

Combs, J. G., Ketchen Jr, D. J., and Short, J. C., 2011. Franchising research: Major milestones, new directions, and its future within entrepreneurship. Entrepreneurship Theory and Practice, 35(3), 413-425.

Croonen, E. P., and Brand, M., 2013. Antecedents of franchisee responses to franchisor-initiated strategic change. International Small Business Journal, 0(0), 1-23.

Chu, C. N., and Liu, W. M., 2010. General Equilibrium Analysis of Hold-Up Problem and Non-Exclusive Franchise Contract. Pacific Economic Review, 15(5), 674-684.

Cuevas-Rodríguez, G., Gomez-Mejia, L. R., and Wiseman, R. M., 2012. Has agency theory run its course? Making the theory more flexible to inform the management of reward systems. Corporate Governance: An International Review, 20(6), 526-546. 
Cumberland, D., and Githens, R., 2012. Tacit knowledge barriers in franchising: practical solutions. Journal of Workplace Learning, 24(1), 48-58

Dada, O. L., and Watson, A., 2012. The effect of entrepreneurial orientation on the franchise relationship. International Small Business Journal. 0 (0) 1-23

Dada, O. L., Watson, A., and Kirby, D. A., 2010. Toward a model of franchisee entrepreneurship. International Small Business Journal. 30(5), 1-25

Dant, R. P., 2008. A futuristic research agenda for the field of franchising. Journal of Small Business Management, 46(1), 91-98.

Desai, P. S., 1997. Advertising fee in business-format franchising. Management Science, 43(10), 1401-1419.

Eisenhardt, K. M., 1989. Agency theory: An assessment and review. Academy of Management Review, 14(1), 57-74.

El Akremi, A., Mignonac, K., and Perrigot, R., 2010. Opportunistic behaviors in franchise chains: The role of cohesion among franchisees. Strategic Management Journal, 32(9), 930-948.

Fama, E. F., and Jensen, M. C., 1983a. Separation of ownership and control. Journal of Law and Economics, 26, 301-325.

Fama, E. F., and Jensen, M. C., 1983b. Agency problems and residual claims. Journal of Law and Economics, 26, 327-349.

Fladmoe-Lindquist, K., 1996. International franchising: capabilities and development. Journal of Business Venturing, 11(5), 419-438.

Gasset, J. R., 1992. La franquicia: una estrategia de expansión. Escuela de administración de empresas de Barcelona.

Gillis, W., and Castrogiovanni, G. J., 2012. The franchising business model: an entrepreneurial growth alternative. International Entrepreneurship and Management Journal, 8(1), 75-98.

Gonzalez-Diaz, M., and Solis-Rodriguez, V., 2012. Why do entrepreneurs use franchising as a financial tool? An agency explanation. Journal of Business Venturing, 27(3), 325341.

Gorovaia, N., and Windsperger, J., 2013. Determinants of knowledge transfer strategy in franchising: integrating knowledge-based and relational governance perspectives. The Service Industries Journal, 33(12), 1117-1134.

Grace, D., and Weaven, S., 2011. An empirical analysis of franchisee value-in-use, investment risk and relational satisfaction. Journal of Retailing, 87(3), 366-380.

Hossain, T., and Wang, S., 2008. Franchisor's Cumulative Franchising Experience and Its Impact on Franchising Management Strategies. Journal of Marketing Channels, 15(1), 43-69.

Hua, N., and Dalbor, M. C., 2013. Evidence of franchising on outperformance in the restaurant industry: A long term analysis and perspective. International Journal of Contemporary Hospitality Management, 25(5), 723-739.

IFA (International Franchising Association), 2016. Franchise Business Economic Outlook for 2016. Disponible on line, consultado el 10 de junio de 2016: http://www.franchise. org/sites/default/files/EconomicOutlookInfographic_January2016.pdf

Jensen, M. C., and Meckling, W. H., 1976. Theory of the firm: Managerial behavior, agency costs and ownership structure. Journal of Financial Economics, 3(4), 305-360. 
Juste, M. V. B., Palacios, L. L., and Redondo, Y. P., 2006. Valoración de los recursos intangibles: un análisis empírico para el sector de la franquicia. Información Comercial Española, ICE: Revista de Economía (829), 177-188.

Kaufmann, P. J., 1999. Franchising and the choice of self-employment. Journal of Business Venturing, 14(4), 345-362.

Kaufmann, P. J., and Eroglu, S., 1999. Standardization and adaptation in business format franchising. Journal of Business Venturing, 14(1), 69-85.

Lafontaine, F., 1992. Agency theory and franchising: some empirical results. The RAND Journal of Economics, 23(2), 263-283.

Lafontaine, F., and Bhattacharyya, S., 1995. The role of risk in franchising. Journal of Corporate Finance, 2(1), 39-74.

Letza, S., Kirkbride, J., and Sun, X., 2004. Shareholding versus stakeholding: A critical review of corporate governance. Governance: An International Review, 12(3), 242-262.

Marie Doherty, A., Chen, X., and Alexander, N., 2014. The franchise relationship in China: agency and institutional theory perspectives. European Journal of Marketing, 48(9/10), 1664-1689.

Mellewigt, T., Ehrmann, T., and Decker, C., 2011. How does the franchisor's choice of different control mechanisms affect franchisees' and employee-managers' satisfaction? Journal of Retailing, 87(3), 320-331.

Michael, S. C., 2014. Can franchising be an economic development strategy? An empirical investigation. Small Business Economics, 42(3), 611-620.

Michael, S. C., and Combs, J. G., 2008. Entrepreneurial failure: the case of franchisees*. Journal of Small Business Management, 46(1), 73-90.

Michael, S. C., and Moore, H. J., 1995. Returns to franchising. Journal of Corporate Finance, 2(1), 133-155.

Mumdžiev, N., and Windsperger, J., 2011. The structure of decision rights in franchising networks: a property rights perspective. Entrepreneurship Theory and Practice, 35(3), 449-465.

Norton, S. W., 1988. An empirical look at franchising as an organizational form. Journal of Business, 61(2), 197-218.

Nyadzayo, M. W., Matanda, M. J., and Ewing, M. T., 2015. The impact of franchisor support, brand commitment, brand citizenship behavior, and franchisee experience on franchisee-perceived brand image. Journal of Business Research, 68, 1886-1894.

Okoroafor, H., 2014. The barriers to tacit knowledge sharing in franchise organizations. Knowledge Management Research \& Practice, 12(1), 97-102.

Pardo-del-Val, M., Martínez-Fuentes, C., López-Sánchez, J. I., and Minguela-Rata, B., 2014. Franchising: the dilemma between standardisation and flexibility. The Service Industries Journal, 34(9-10), 828-842.

Pena, I., 2002. Intellectual capital and business start-up success. Journal of Intellectual Capital, 3(2), 180-198.

Petty, R., and Guthrie, J., 2000. Intellectual capital literature review: measurement, reporting and management. Journal of Intellectual Capital, 1(2), 155-176.

Ring, P. S., and Van de Ven, A. H., 1994. Developmental processes of cooperative interorganizacional relationships. Academy of Management Review, 19(1), 90-118. 
Ross, S. A., 1973. The economic theory of agency: The principal's problem. The American Economic Review, 63, 134-139.

Rubin, P. H., 1973. Expansion of firms. Journal of Political Economy, 81(4), 936-949.

Rubin, P. H., 1978. The theory of the firm and the structure of the franchise contract. Journal of Law and Economics, 21, 223-233.

Salar, M., and Salar, O., 2014. Determining pros and cons of franchising by using swot analysis. Procedia-Social and Behavioral Sciences, 122, 515-519.

Seawright, K. W., Smith, I. H., Mitchell, R. K., and McClendon, R., 2013. Exploring Entrepreneurial Cognition in Franchisees: A Knowledge-Structure Approach. Entrepreneurship Theory and Practice, 37(2), 201-227.

Shane, S. A., 1998. Making new franchise systems work. Strategic Management Journal, 19(7), 697-707.

Shane, S., and Venkataraman, S., 2000. The promise of entrepreneurship as a field of research. Academy of Management Review, 25(1), 217-226.

Sigué, S. P., and Chintagunta, P., 2009. Advertising strategies in a franchise system. European Journal of Operational Research, 198(2), 655-665.

Stewart, T., and Ruckdeschel, C., 1998. Intellectual capital: The new wealth of organizations. New York: Currency Doubleday.

Teece, D. J., Pisano, G., and Shuen, A., 1997. Dynamic capabilities and strategic management. Strategic Management Journal, 18(7), 509-533.

Vázquez, L., 2005. Las compensaciones en las relaciones de franquicia. Revista de Economía Aplicada, 13(38), 111-122.

Vázquez, L., 2007. Determinants of contract length in franchise contracts. Economics Letters, 97(2), 145-150.

Venkataraman, S., 1997. The distinctive domain of entrepreneurship research. Advances in Entrepreneurship, Firm Emergence and Growth, 3(1), 119-138.

Watson, A., and Stanworth, J., 2006. Franchising and intellectual capital: A franchisee's perspective. The International Entrepreneurship and Management Journal, 2(3), 337349.

Wernerfelt, B., 1984. A resource-based view of the firm. Strategic Management Journal, 5(2), 171-180.

Wimmer, B. S., and Garen, J. E., 1997. Moral hazard, asset specificity, implicit bonding, and compensation: The case of franchising. Economic Inquiry, 35(3), 544-554.

Windsperger, J., and Dant, R. P., 2006. Contractibility and ownership redirection in franchising: A property rights view. Journal of Retailing, 82(3), 259-272.

Winter, S. G., Szulanski, G., Ringov, D., and Jensen, R. J., 2012. Reproducing knowledge: inaccurate replication and failure in franchise organizations. Organization Science, 23(3), 672-685.

Zander, U., and Kogut, B., 1995. Knowledge and the speed of the transfer and imitation of organizational capabilities: An empirical test. Organization Science, 6(1), 76-92. 
